\title{
OSSEOUS DYSTROPHY FOLLOWING ICTERUS GRAVIS NEONATORUM
}

\author{
BY
}

FRANCES BRAID, M.D., M.R.C.P., Physican, Children's Hospital; Assistant Physician, Maternity Hospital, Birmingham.

It seems desirable to put on record the fact that two very unusual conditions, icterus gravis and osseous dystrophy, have occurred in one and the same child. That the two conditions have some interdependence is at least an interesting speculation.

\section{Case report.}

R. T., male, born on 5th November, 1928, was the second child of healthy parents. At birth he weighed $7 \mathrm{lb} .10 \mathrm{oz}$. His mother was well throughout the pregnancy, and her first child had always been healthy. About the second day he became jaundiced, but his condition did not arouse anxiety until the tenth day when he bled profusely from the mouth and umbilicus, and on that account he was admitted to the Nursery of the Birmingham Maternity Hospital. When first seen, he looked extremely ill, was deeply jaundiced and bleeding freely. A single dose (5 c.cm.) of whole blood, given intra-muscularly, caused prompt arrest of the bleeding; but, for the next three weeks, his condition remained critical. The jaundice was apparently stationary and the stools were consistently colourless. Repeated chemical tests for bile salts and bile pigment in the stools were negative. The liver and the spleen were not appreciably enlarged. His weight fell to $5 \mathrm{lb} .9 \mathrm{oz}$. at four weeks. Then a gradual improvement set in, and the stools began to assume a normal colour. On 8th December bile pigment was present in the fæces, but bile salts were still absent. He was entirely breast-fed and at the age of seven weeks he was able to go home. The yellow staining of his skin persisted for many weeks so that an extensive brown birth-mark on his face and neck was not noted until he was between four and five months old; but his general progress was good. At six months he had two teeth, and at eleven months he had seven teeth and was $15_{2}^{\frac{1}{2}} \mathrm{lb}$. in weight.

During this period, the fat content of the stools had been estimated on threo occasions (Table 1).

TABLE 1.

Estimation of fat in fefces at 2, 6, and 9 montis.

\begin{tabular}{|c|c|c|c|c|}
\hline \multirow{2}{*}{ Date } & \multirow{2}{*}{$\begin{array}{l}\text { Total fat in dried } \\
\text { fæces }\end{array}$} & \multicolumn{3}{|c|}{ Percentage of færal fat } \\
\hline & & $\begin{array}{l}\text { Neutral } \\
\text { fat }\end{array}$ & $\begin{array}{l}\text { Fatty } \\
\text { acid }\end{array}$ & Soap \\
\hline Jan. 5, 1929 & $66 \cdot 5 \%$ & $17 \cdot 9$ & $25 \cdot 7$ & $56 \cdot 4$ \\
\hline May 28, 1929 & $30 \cdot 2 \%$ & $41 \cdot 8$ & $29 \cdot 4$ & $25 \cdot 9$ \\
\hline Aug. 13, 1929 & $25 \cdot 3 \%$ & $6 \cdot 7$ & $47 \cdot 4$ & $45 \cdot 9$ \\
\hline
\end{tabular}


About a year later, in response to my enquiry concerning his progress, his mother brought him to see me. He appeared to be very well apart from a certain degree of secondary anæmia:- red cells 3,755,000, hæmoglobin 58 per cent.; white

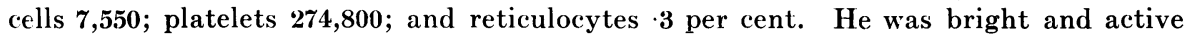
in his movements, his mental development was up to normal standard and there was no lesion of his central nervous system. The only complaint was that he was unsteady on his feet. The reason for that became apparent a few months later when persistent pain in one thigh, after a fall, led to an X-ray examination being made and so to the discovery of a cystic condition of the shafts of all the long bones. On that account, he was admitted to the hospital, early in 1931, and submitted to various investigations.

Calcium and phosphorus metabolism.- The child was fed on Almata and milk, a complete food, for a week and on the second three days estimations were made. The results showed that calcium and phosphorus metabolism was within normal limits (Table 2).

TABLE 2.

Calcium and phosphorus estimations. April 18-20, 1931.

\begin{tabular}{|c|c|c|c|c|c|c|}
\hline & \multicolumn{4}{|c|}{ Daily average (grm.) } & \multirow{2}{*}{$\begin{array}{l}\text { Absorbed } \\
\text { grm. }\end{array}$} & \multirow{2}{*}{$\begin{array}{c}\text { Retained } \\
\text { grm. }\end{array}$} \\
\hline & Intake & $\begin{array}{l}\text { Fæcal } \\
\text { ouiput }\end{array}$ & $\begin{array}{l}\text { Urinary } \\
\text { output }\end{array}$ & $\begin{array}{l}\text { Total } \\
\text { output }\end{array}$ & & \\
\hline Calcium & $1 \cdot 1788$ & $\cdot 373$ & .011 & $\cdot 384$ & $\begin{array}{c}\cdot 8058 \\
(68 \cdot 3 \%)\end{array}$ & $\begin{array}{c}\cdot 7948 \\
(67 \cdot 4 \%)\end{array}$ \\
\hline Phosphorus & $\cdot 9641$ & $\cdot 1406$ & $\cdot 3340$ & .4746 & $\begin{array}{c}.8235 \\
(85.4 \%)\end{array}$ & $\begin{array}{c}\cdot 4895 \\
(50 \cdot 8 \%)\end{array}$ \\
\hline
\end{tabular}

Fat excretion. - Fat excretion as estimated in the stools of three successive days was within normal limits. The slightly high total daily fat excretion in the third analysis was most probably due to the fact that the baby had recently had an operation for acute mastoiditis and was not wholly convalescent (Table 3).

TABLE 3.

Estimation OF F.eCAL FAT: AVERAGE OF THREF DAYs.

\begin{tabular}{|c|c|c|c|c|c|c|}
\hline \multirow[b]{2}{*}{ Date } & \multirow[b]{2}{*}{ Diet } & \multirow{2}{*}{$\begin{array}{l}\text { Total fat } \\
\text { in dried } \\
\text { fæces }\end{array}$} & \multicolumn{3}{|c|}{ Percentage of fæcal fat } & \multirow{2}{*}{$\begin{array}{l}\text { Excretion } \\
\text { per day } \\
\text { grm. }\end{array}$} \\
\hline & & & $\begin{array}{l}\text { Neutral } \\
\text { fat }\end{array}$ & $\begin{array}{l}\text { Fatty } \\
\text { acid }\end{array}$ & Soap & \\
\hline $\begin{array}{l}\text { April } \\
22.31\end{array}$ & $\underset{\text { milk }}{\text { Almata }} \&$ & $39 \cdot 1 \%$ & $31 \cdot 5$ & $9 \cdot 7$ & $58 \cdot 8$ & $1 \cdot 8$ \\
\hline $\begin{array}{l}\text { May } \\
17.31\end{array}$ & $\begin{array}{c}\text { Ordinary } \\
\text { diet }\end{array}$ & $29 \cdot 3^{\circ}$ & $11 \cdot 7$ & $40 \cdot 6$ & $47 \cdot 8$ & $1 \cdot 2$ \\
\hline $\begin{array}{l}\text { April } \\
12.32\end{array}$ & $\begin{array}{c}\text { Ordinary } \\
\text { diet }\end{array}$ & $25 \cdot 2 \%$ & $12 \cdot 7$ & $29 \cdot 4$ & $58 \cdot 0$ & $2 \cdot 4$ \\
\hline
\end{tabular}


Bones.-X-ray examinations have been made from time to time and the cystic condition of the shafts of all the long bones has remained fairly constant. The epiphyses do not appear to be involved (Fig. 1).

While kept at rest, deformity of the limbs has remained slight but since he has been allowed to sit up, he has developed a kyphosis and a certain degree of forward curvature of the sternum (Fig. 2).

Eruption of the teeth and the condition of the teeth have been normal.
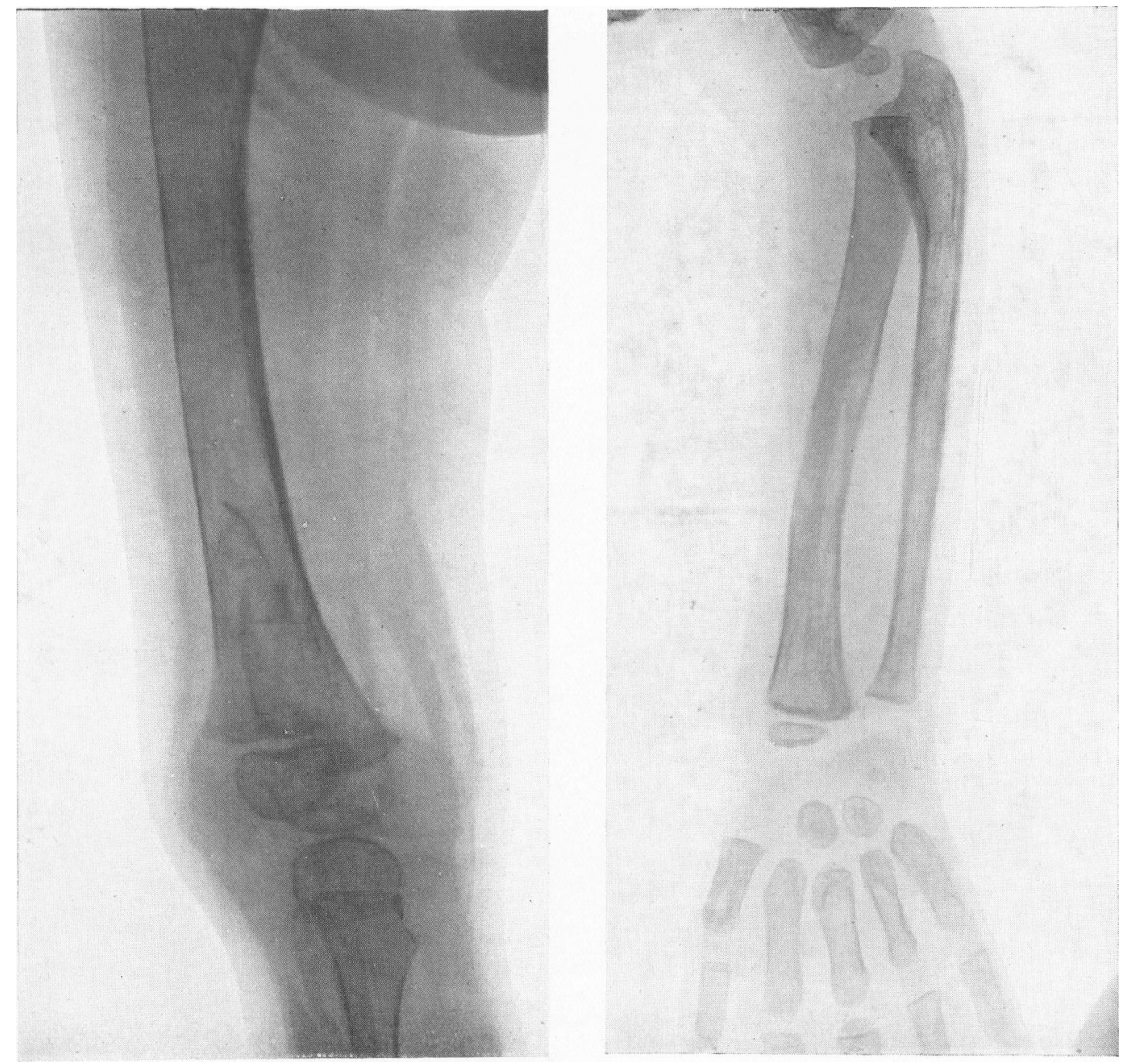

FIG. 1.-Skiagrams showing cystic condition of bones.

Other investigations.-Examination of the urine was negative, and the blood urea as estimated on 8th March, 1932, was $23.5 \mathrm{mgrm}$. per cent. The Wassermanil reactions of the child and of his mother were negative.

Course.-He has passed through a severe attack of measles, an attack of chickenpox and an acute mastoiditis for which a radical operation was necessary, all without any untoward happening. His general health is good and, mentaily, he 
is very alert (Fig. 2). The condition of his bones has altered very little and there has been no definite deterioration other than a slight increase in rarefaction, such as might be accounted for by these acute illnesses. If the blood phosphatase, as estimated by the method described by $\mathrm{Kay}^{1}$, may be taken as a guide then an improvement is suggested by its fall from $\cdot 86$ in June, 1931, to 32 in April, 1932. It seems probable that there may be an ultimate spontaneous cure when growth has ceased.

Various treatments have been tried in turn: ultra-violet light, radiostoleum, thymus extract and raw thymus, and various liver preparations. Throughout, a

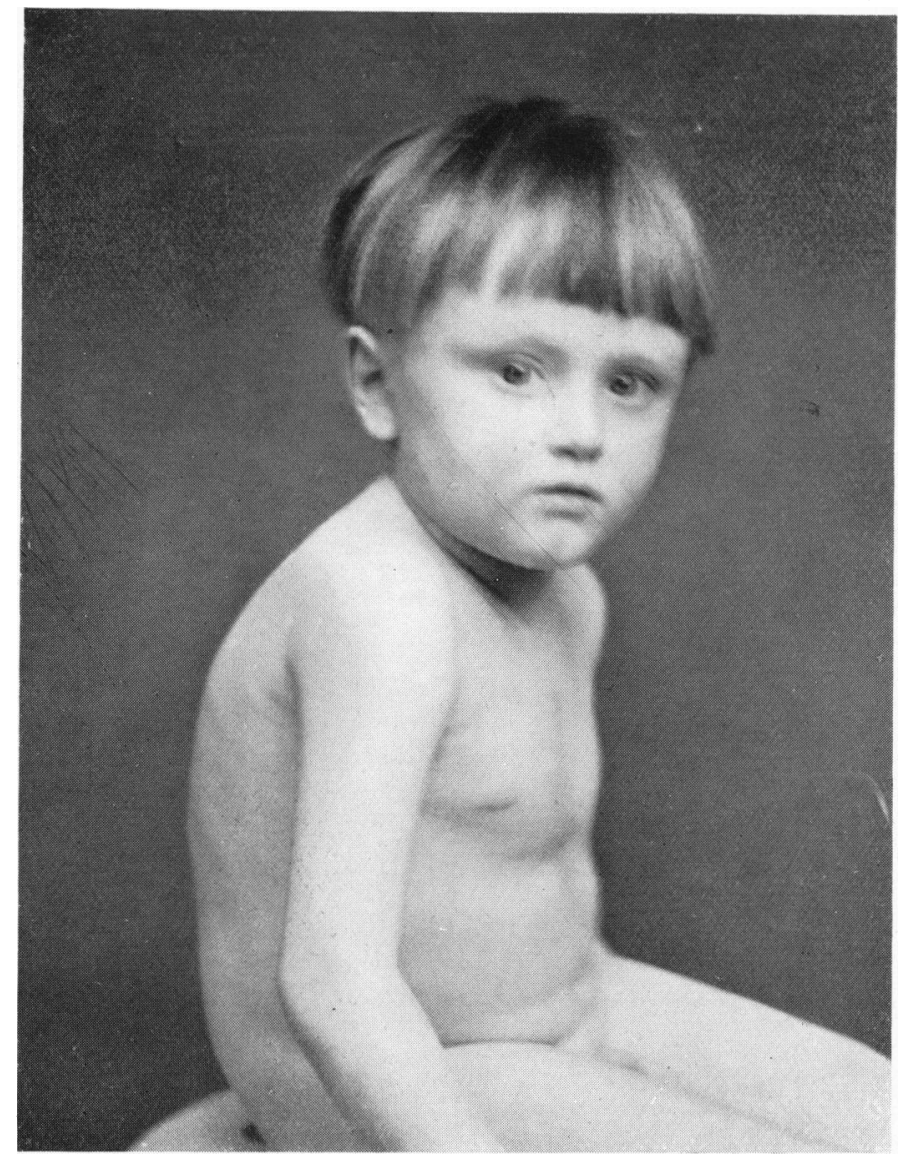

Fig. 2.-Showing kyphosis and curvature of sternum.

suitable diet and additional salts were given. No treatment has had any effect and the chief practical consideration has been the prevention of deformity.

\section{Discussion.}

Into which category should one place the jaundice of the early weeks of life in this case? My original diagnosis was congenital obliteration of the bile-ducts, but the subsequent progress of the case dismissed that possibility. It is interesting to note here, however, that, in his classical paper on 
congenital obliteration of the bile-ducts, Thomson ${ }^{2}$ included seven cases in which, at autopsy, the ducts were found to be pervious. Two of these had passed white stools, and in five there had been hæmorrhage from the umbilicus. The average life of these cases was seventeen and a half days, in contrast to an average of two and a half months in those in which the bile-ducts had been found to be impervious. It is very probable that these cases and the one here reported are similar, and fall into the group of familial icterus gravis. In the present case that diagnosis is supported by the fact that in January, 1931, another brother was born, who was deeply jaundiced, who bled and who recovered completely on treatment with repeated injections of whole blood.

The dramatic improvement in cases of familial icterus gravis neonatorum when treated with maternal serum or whole blood as recommended by Hampson $^{3}$, and the good immediate results, intensify the disappointment experienced on watching the subsequent development of some of these children. That a profound disturbance of the central nervous system, as described by Spiller ${ }^{4}$ and shown in cerebral diplegia and mental deficiency, may result is accepted, and has happened in one of my cases. That there may be a less severe disturbance, and one from which recovery may take place, is suggested by the extreme muscular atony which occurred in another of my cases. This was a striking feature at age eleven months and a few months later great improvement was reported. It seems possible that osseous dystrophy may be another direct sequel.

That calcium metabolism is disturbed in jaundice has been shown by many workers (reviewed by $\mathbf{I v y}^{5}$ ), although they are not in agreement as to the mode or type of disturbance. In relation to the case under consideration, the work of Buchbinder and $\mathrm{Kern}^{6}$ is of most interest. They have shown that the age factor is all important in determining the changes in blood calcium in obstructive jaundice. Puppies showed a definite decrease in serum calcium and disturbance of bony structure, whereas little or no disturbance occurred in adult dogs. In puppies, they produced jaundice by ligaturing the common bile-duct. Between the 20th and the 60th days there was a fall in the blood calcium. During this time there was skeletal growth. At 20 days there were no bone changes but after 60 to 70 days there was ' a high grade rarefaction, cortical thinning with relatively wide medullary spaces and a lack of contrast generally . . . One animal developed bilateral cysts in the bones.' They also produced evidence to show that there is some alteration of the parathyroid function in obstructive jaundice in animals. The disturbance produced by thyro-parathyroidectomy is much less severe in chronically jaundiced animals, and tetany does not appear in late obstructive jaundice in puppies in which the serum calcium has fallen to the tetany level.

In bile-fistula dogs, that is in dogs in which the bile is prevented from entering the intestine but in which the liver itself is not injured, Whipple ${ }^{7}$ has shown that bony abnormalities develop, but can be cured or prevented by feeding with whole liver, 
These findings suggest that the altered calcium metabolism in obstructive jaundice in young animals depends on something other than mere absence of bile from the intestine and consequent diminished absorption of fat and calcium. It seems likely that the liver has some concern with calcium metabolism and therefore with normal growth of bone and nerve tissue; and it is accepted that pathological changes in bone and at least functional changes in the nervous system and extreme muscular atony do occur in different cases of rickets, and are all due to the same initial cause. What determines the predominance of one or other feature is not fully known, but Mellanby's ${ }^{8}$ experimental work suggests a possible reason for the

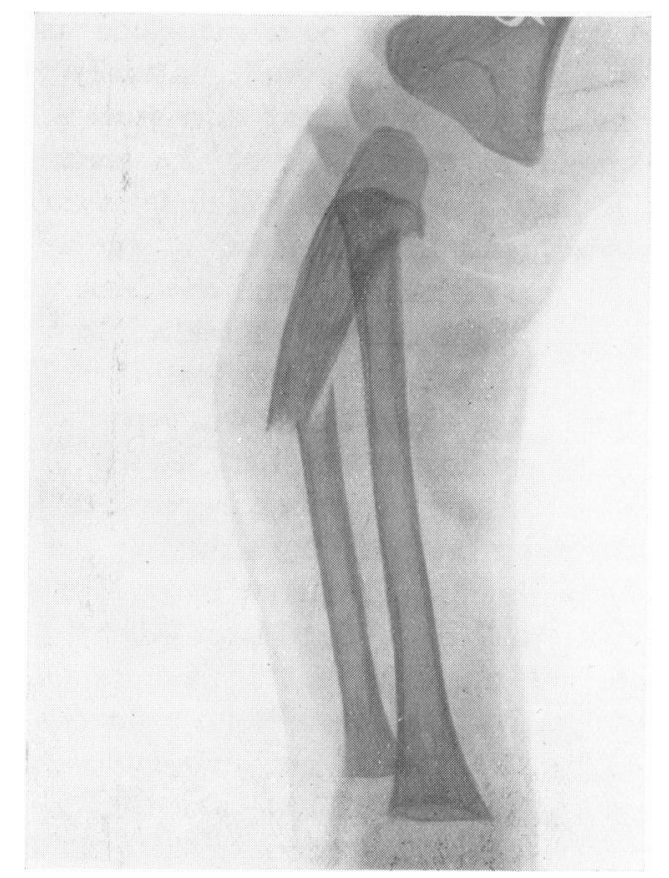

FIG. 3.-Showing osteoporosis and spontaneous fracture in a case of kernicterus.

muscular atony. Under certain dietetic conditions Mellanby was able to produce in dogs a combination of severe inco-ordination and muscular weakness. The spinal cord in these animals showed in various tracts a scattered degeneration which he regarded as mainly due to an absence of vitamin A from the diet. Bone changes and nerve changes in rickets are due to lack of vitamins A and D. Harris ${ }^{9}$ lays stress on the importance of $\mathbf{A}$ as well as $\mathbf{D}$ in normal ossification. It is not unlikely, then, that parallel conditions will ensue if the factor controlling the utilization of the vitamins is impaired or destroyed. The liver is the main storehouse of vitamins and presumably controls their optimum distribution and activity. This hypothetical speria! 
function may well be affected in the profound disturbance of all liver functions in prolonged jaundice. The exact nature of the pathological changes in the central nervous system in icterus gravis is an open question, but it is possible that a common cause, common to them and to the pathological changes in the bones in this case, may be found in an impairment or destruction of a liver function concerned with the utilization of vitamins, particularly $\mathbf{A}$ and $\mathbf{D}$. This may be allied to, or independent of, a failure of the liver to incorporate the vitamins, a failure which Green ${ }^{10}$ has demonstrated in some puerperal cases.

The survival of infants suffering from icterus gravis has been rare until recently, and it is not surprising that $I$ have failed to find a previous report of the combination of conditions here described, or a record of a case showing similar features in the bones. When I saw this child in 1928, I was unaware of the importance of pushing the treatment with adult serum or blood, and gave only sufficient to arrest the bleeding. That may explain the unusually long duration of the jaundice. Subsequent cases have been treated more generously, but one of them who also developed cerebral diplegia, showed a general osteoporosis and had a spontaneous fracture (Fig. 3).

\section{Summary.}

1. A case of osseous dystrophy following icterus gravis neonatorum is reported.

2. Work on experimentally jaundiced puppies producing similar bone changes is discussed.

3. A comparison is made between the bone and nerve changes in rickets, and the bone and nerve changes following icterus gravis neonatorum.

4. It is suggested that the liver not only stores vitamins but controls their distribution and activities in normal conditions.

5. This function may be impaired or destroyed in prolonged jaundice, and, occurring in infancy, a pathological condition of bones as well as of nervous tissue may ensue.

I am very much indebted to Dr. E. M. Hickmans for the biochemical reports, and to Dr. C. G. Teall, Radiologist to the Children's Hospital for making many $\mathrm{X}$-ray examinations.

\section{REFERENGES.}

1. Kay, H. D., Brit. J. Exp. Path., Lond., 1929, X, 253.

2. Thomson, J., Edinb. Med. J., Edinb., 1892, XXXVII, 727.

3. Hampson, A. C., Guy's Hosp. Rep., Lond., 1928, LXXVIII, 199; Lancet, Lond., 1929, i, 429; Brit. Med. J., Lond., 1931, ii, 932.

4. Spiller, W. G., Am. J. Med. Sc., Philad., 1915, CXLIX, 345. 
5. Ivy, A. C., J. Am. Med. Ass., Chicago, 1930, XCIX, 1068.

6. Buchbinder, W. C., \& Kern, R., Am. J. Physiol., Balt., 1927, LXXX, 273; Arch. Int. Med., Chicago, 1927, XL, 900, \& 1928, XLI, 754.

7. Whipple, G. H., Physiol. Rev., Balt., 1922, ii, 440.

8. Mellanby, E., J. Am. Med. Ass., Chicago, 1931, XCVI, 325; Brit. Med. J., Lond.. 1930, i, 677; Brain, Lond., 1931, LIV, 247.

9. Harris, H. A., Am. J. Med. Sc., Philad., 1931, CLXXXI, 450.

10. Green, H. N., Lancet, Lond., 1932, ii, 723. 